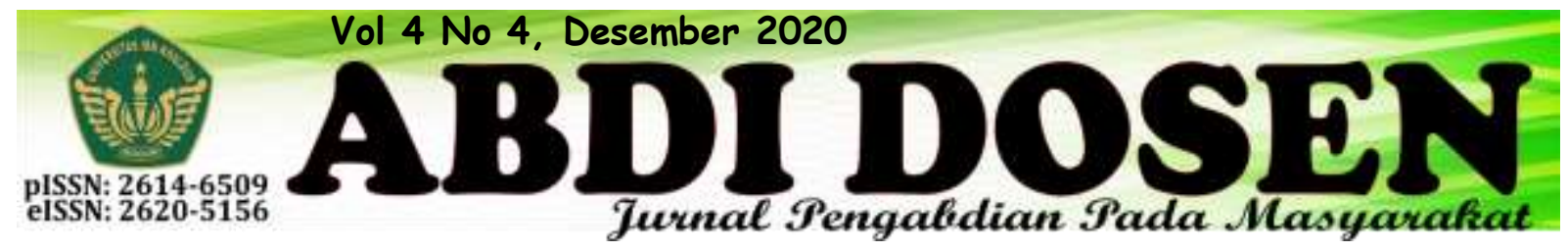

\title{
MENINGKATKAN MUTU MASYARAKAT MELALUI BIDANG PENDIDIKAN DAN KESEHATAN DALAM RANGKA MEWUJUDKAN STABILITAS EKONOMI DAN SOSIAL
}

\author{
Fety Fatimah ${ }^{1}$ dan Rusdi Kasman ${ }^{2}$ \\ fety.fatimah@uika-bogor.ac.id ${ }^{1}$ \\ rusdikasman@uika-bogor.ac.id ${ }^{2}$ \\ Dosen Fakultas Teknik dan Sains ${ }^{1}$, Dosen Fakultas Keguruan dan Ilmu Pendidikan ${ }^{2}$
}

\begin{abstract}
ABSTRAK
Kuliah Kerja Nyata atau disingkat KKN merupakan kegiatan pengabdian kepada masyarakat di daerah tertentu atau lembaga pendidikan, dilaksanakan secara kelompok, terintegrasi antar jurusan, terkoordinasi ditingkat fakultas, memiliki enam bidang unggulan, antara lain, aspek pendidikan, hukum, kesehatan, teknik, ekonomi dan agama Islam. Kegiatan KKN bertujuan untuk memberikan pengalaman kerja nyata bagi mahasiswa di masyarakat dalam membentuk sikap mandiri dan tanggung jawab serta membantu masyarakat dalam meningkatkan taraf pendidikan dan keterampilan, sehingga diharapkan dapat meningkatkan kesejahteraan hidupnya. Kegiatan KKN tahun 2019 dilaksanakan di kampung Tipar, Desa Batujajar Kecamatan Cigudeg Kabupaten Bogor. Kegiatan KKN dilaksanakan dalam durasi waktu 30 hari yaitu dari tanggal 6 Agustus sampai 6 September 2019. Adapun kegiatan prioritas adalah kegiatan Pendidikan, Lingkungan dan Kesehatan. Kegiatan pendidikan, meliputi pemberdayaan tenaga pendidik di PAUD, edukasi tentang kewirausahaan; kegiatan lingkungan meliputi kegiatan pola hidup bersih dan pembuatan bak sampah; kegiatan kesehatan meliputi penyuluhan kesehatan, kegiatan Pola Hidup Sehat dan Bersih, serta membangun budaya lingkungan bersih.
\end{abstract}

\section{Kata Kunci : KKN, Desa Batujajar, Cigudeg}

\section{PENDAHULUAN}

\section{Analisis Situasi}

KKN adalah suatu bentuk pendidikan dengan cara memberikan pengalaman belajar kepada mahasiswa untuk hidup di tengah-tengah masyarakat, secara terstruktur melalui beberapa tahap diantaranya persiapan, pembekalan dan observasi sampai pada tahap evaluasi (Rosyadi, 2019).

KKN yang dilaksanakan kali ini berlokasi di Desa Batu Jajar kecamatan Cigudeg. Secara monografi, jumlah pendduduk di Desa Batu Jajar berjumlah

5.723 jiwa dengan tingkat kepadatan 320jiwa $/ \mathrm{km}^{2}$. Wilayah desa Batu Jajar sebelah utara berbatasan dengan Parung Panjang, sebelah timur berbatasan dengan Rumpin, sebelah selatan berbatasan dengan desa Rengasjajar dan desa Tegallega dan sebelah barat berbatasan dengan desan Rengasjajar dan Rumpin (wikipedia, 2019).

Untuk memperoleh gambaran lokasi dan permasalahan yang dihadapi oleh masyarakat di desa tujuan, maka kegiatan utama yang dilakukan adalah identifikasi 
masalah dan lingkungan. Berdasarkan hasil identifikasi tersbut lokasi KKN kelompok 55-56 tahun 2019 di desa Batujajar berlokasi di kampung Tipar.

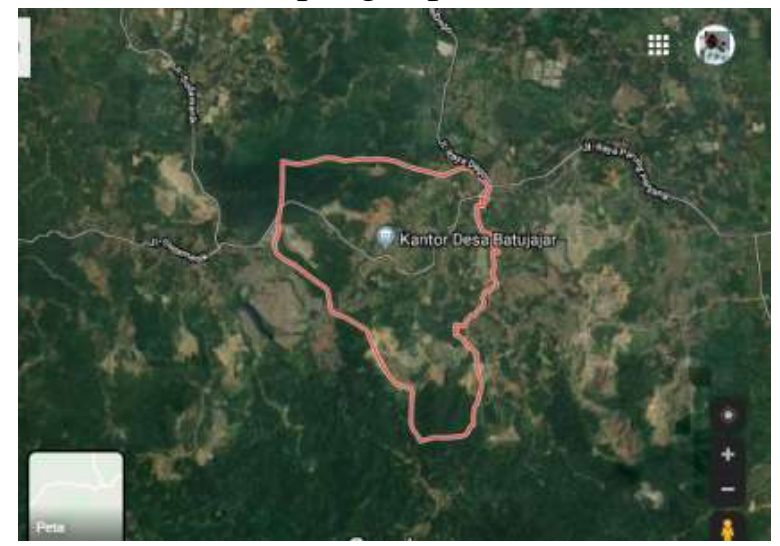

Gambar 1. Peta Desa Batu Jajar

Kampung Tipar merupakan merupakan salah satu yang terletak di Desa Batu Jajar, Kecamatan Cigudeg, Kabupaten Bogor. Sebagian besar wilayah di kampung ini adalah persawahan. Masyarakat desa Batu Jajar pada umumnya merupakan petani, pedagang dan pengemudi truk batu. Melihat dari mata pencaharian masyarakat dan kegiatan sehari-hari dapat disimpulkan bahwa potensi dari Desa Batu Jajar adalah pada bidang pertanian. Selain itu, kondisi lingkungan di kampung Tipar telah mengalami erosi dan deteriorasi lingkungan alam akibat kegiatan galian atau pengerukan gunung. Adapun kondisi pendidikan, di desa Tipar terdapat empat sekolah. terdiri dari : 2 PAUD dan 2 SDN, sedangkan SMP dan SMA sederajat belum ada. Secara keseluruhan jumlah SMP dan sederajat di desa Batu Jajar berjumlah 1 buah, sedangkan SMA atau sederajat tidak ada.

\section{Permasalahan Ditemukan}

Berdasarkan analisis situasi dan observasi yang dilakukan, maka terdapat permasalahan di Desa Batu Jajar, diantaranya:
1. Permasalahan minimnya kualitas Pendidikan berupa profesionalitas tenaga pendidik dan kurangnya sarana dan prasarana pendidikan di Desa Batu Jajar dalam membantu pembelajaran siswa.

2. Permasalahan lingkungan berupa pengelolaan sampah dan lingkungan bersih

3. Permasalahan ekonomi kreatif masyarakat

4. Permasalahan kekerasan perempuan dan anak

\section{Solusi Permasalahan}

Setelah menganalisis beberapa permasalahan yang terjadi di Desa Batu Jajar, maka kami menetapkan beberapa program KKN sebagai solusi permasalahan di desa Batu Jajar, di antaranya:

1. Bidang Pendidikan

Program kerja pada bidang ini meliputi,

a. Program pendampingan pembelajaran di PAUD dan SD, Kegiatan ini bantuan kegiatan mengajar

b. Kegiatan Bimbingan belajar bagi anak SD. Kegiatan tersebut bersifat sementara, sebab pendampingan langsung dilakukan oleh mahasiswa KKN,

c. Program seminar pengembangan kualitas tenaga pendidik dan orang tua. Kegiatan tersebut dilakukan dengan edukasi langsung dari pakar pendidikan bagi guru dan orang tua murid di PAUD. Kegiatan ini dilakuan sebagai bentuk pengembangan kompetensi tenaga pendidik. Di dalam Undang-undang Nomor 14 Tahun 2005 tentang Guru dan Dosen, terdapat empat kompetensi yang harus dipenuhi guru, yaitu kompetensi pedagogik, 
kepribadian, profesional, dan kompetensi sosial. Untuk meningkatkan kompetensi tersebut diperlukan penuugasan dan pembelajaran dan pelatihan bagi guru (Sudarwan Danim, 2002).

2. Bidang Keagamaan

Program kerja pada bidang ini meliputi,

a. Program bimbingan mengaji kepada anak anak dalam membantu pembacaan huruf hijaiyah dan pengetahuan agama lainnya,

b. Program pengajian untuk peningkatan kualitas iman dan taqwa bagi warga.

3. Bidang Kesehatan

Program kerja pada bidang ini meliputi,

a. Program penyuluhan kesehatan cara Perilaku Hidup Bersih dan Sehat (PHBS) di sekolah dasar di SDN Batu Jaja. Manfaat PHBS mengupayakan lingkungan sehat dan mencegah dan menanggulangi masalah-masalah kesehatan. (Depkes, 2007 : 23).

b. Program pengecekan kesehatan umtuk lansia di kampung Tipar.

4. Bidang Lingkungan

Program kerja pada bidang ini meliputi,

a. program pemberdayaan lingkungan di kampung Tipar berupa pengadaan bak sampah. Pelaksanaan program ini sebagai upaya menjaga lingkungan tetap bersih dan menghindari penyakit yang disebabkan sampah itu sendiri. Di dalam Undang-Undang no 18 tahun 2008 tentang pengelolaan persampahan. Pasal 3 UU 18/2008 berbunyi selengkapnya: "Pengelolaan sampah diselenggarakan berdasarkan asas tanggung jawab, asas keberlanjutan, asas manfaat, asas keadilan, asas kesadaran, asas kebersamaan, asas keselamatan, asas keamanan, dan asas nilai ekonomi".

b. Program Jumat Bersih

5. Bidang Ekonomi

Program pada bidang ini meliputi,

a. Memberikan inovasi baru terhadap warga kampung Tipar seperti pembuatan bantalan jarum untuk dijual dan memajukan perekonomian masyarakat.

6. Bidang Hukum

Program pada bidang ini meliputi,

a. Program seminar tentang permasalahan kekerasan anak dan perempuan. 


\section{METODE}

Tahapan pelaksanaan untuk kegiatan ini sebagaimana terlihat pada bagian sebagai berikut:

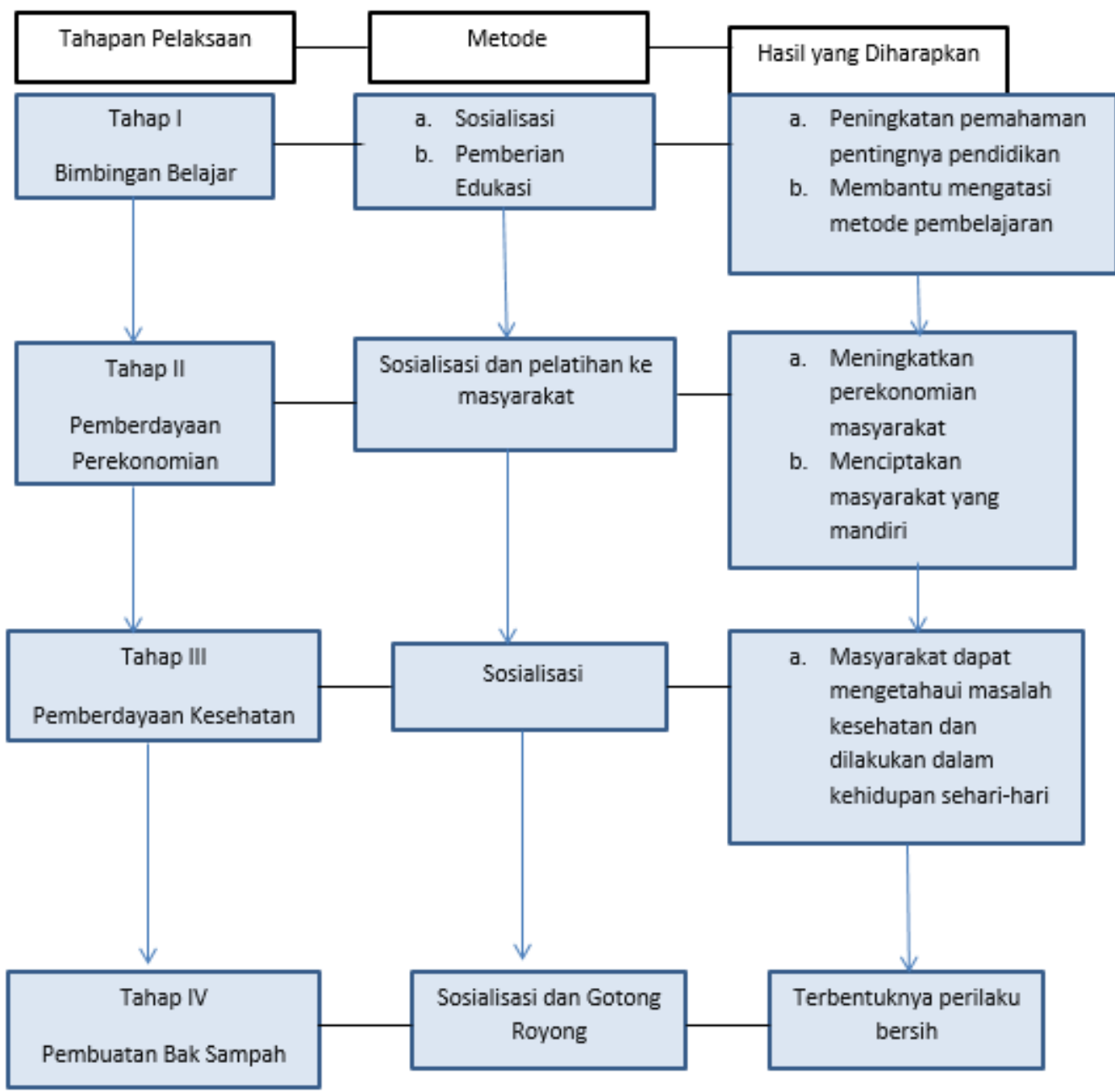

\section{Metode Pendekatan}

Pendekatan yang diterapkan selama 1 bulan di Desa Batu Jajar antara lain, pendekatan organisasi, religius, dan pendekatan edukasi (Rusdi Kasman, 2018:199), pendekatan tersebut di antaranya:

\section{Pendekatan Organisasi}

Organisasi merupakan hal yang memiliki peran penting di tengah-tengah masyarakat. Pendekatan organisasi di lakukan untuk mempermudah pengenalan kami kepada warga Desa Batu Jajar kampung Tipar. Karena suatu himpunan dapat menjadi tolak ukur penilaian terhadap anggota yang tergabung di dalamnya.

2. Pendekatan Religius

Pendekatan religius yang dimaksud adalah pendekatan dengan cara bergabung ke dalam majelis ta'lim ibu ibu maupun bapak bapak. Pendekatan religious ini dianggap perlu dilakukan di desa Batu Jajar

3. Pendekatan Edukasi

Desa Batu Jajar kampung Tipar memiliki masyarakat yang mempunyai latar belakang yang berbeda-beda. Tidak semua masyarakat mempunyai pengetahuan yang lebih modern dalam 
menjalankan kehidupan sehari-hari di lingkungannya. Maka dari itu pendekatan edukasi sangatlah di perlukan untuk mempermudah pendekatan dan pengenalan program kami kepada warga.

\section{Langkah Evaluasi}

Langkah evaluasi yang digunakan dalam kegiatan KKN adalah evaluasi proses dan evlauasi hasil (Fety Fatimah, 2018:143),

1. Evaluasi proses, yakni evaluasi yang terkait dengan perencanaan serta pelaksanaan kegiatan. Evaluasi proses

\section{REALISASI PROGRAM}

1. Bidang Kesehatan

Realisasi program di bidang kesehatan meliputi pemeriksaan kesehatan gratis bagi warga dan kegiatan Pola Hidup Bersih dan Sehat (PHBS) di sekolah.

2. Bidang Pendidikan

Realisasi program dalam bidang pendidikan meliputi kegiatan mengajar di sekolah dasar, kegiatan mengajar dan pendampingan di PAUD, seminar peningkatan kualitas tenaga pendidik dan orang tua di PAUD dan kegiatan bimbingan belajar.

3. Bidang Lingkungan

Realisasi program di bidang lingkungan meliputi kegiatan pembuatan bak sampah untuk mengatisipasi pembuangan sampah ke kali, kegiatan minggu bersih sebagaimana upaya

\section{KESIMPULAN}

Berdasarkan hasil kegiatan, pelaksanaan program kerja KKN yang telah direncanakan, disusun dan dilaksanakan, maka kesimpulan dari kegiatan KKN kelompok 55 dan $56 \mathrm{KKN}$ Tematik Terintegrasi Universitas Ibn akan dilakukan setiap hari oleh seluruh anggota kelompok KKN 55 dan 56.

2. Evaluasi hasil, yakni evaluasi yang akan dilaksanakan setelah kegiatan berlangsung. Evaluasi hasil ditujukan untuk menguji pemahaman warga, sudah sejauh mana mereka mengerti serta paham dengan pembinaan dan seminar yang sudah pernah disosialisasikan oleh mahasiswa KKN kelompok 55 dan 56 Universitas Ibn Khaldun Bogor.

membangun kesadaran kearifan lokal desa setempat.

\section{Bidang Ekonomi}

Kegiatan bidang ekonomi meliputi kegiatan pembuatan tabungan bagi anakanak sekolah untuk membangun pola hidup produktif melalui menabung, kegiatan wakaf dan seminar kewirausahaan untuk meningkatkan ekonomi masyarakat.

5. Bidang Hukum

Penerapan program untuk bidang hukum adalah kegiatan seminar dan edukasi terkait kekerasan anak dan perempuan. Kegiatan ini diselenggarakan se kecamatan Cigudeg.

6. Bidang Keagamaan.

Realisasi program pada bidang keagamaan meliputi, Pengajian Ibu-Ibu dan dan Bapak-Bapak serta Mengajar di TPA

Khaldun Bogor 2019 di Kampung Tipar Desa Batu Jajar Kecamatan Cigudeg Kabupaten Bogor:

1. Permasalahan utama yang dihadapi oleh masyarakat di desa Batu Jajar yang meliputi aspek pendidikan, 
kesehatan, lingkungan dan ekonomi dapat difasilitasi melalui kegiatan pengembangan mutu dan kualitas pendidikan, pendampingan dan bantuan langsung dalam pengajaran serta pembeljaran Qur'an di TPA. Dalam bidang kesehatan difasilitasi melalui program pemeriksaan kesehatan gratis dan penyuluhan Pola Hidup Bersih dan Sehat. Pada bidang lingkungan difasilitasi dengan program pembuatan bak sampah dan kegiatan minggu bersih. Selain itu, kegiatan pendukung dilakukan untuk mengantisipasi permaslahan yang lebih besar, seperti seminar edukasi permasalahan kekerasan anak dan perempuan dan pengembangan nilai-nilai keagamaan atau religiusitas melalui pengajian di majelis taklim.

2. Kerjasama yang ditunjukkan oleh masyarakat di kampung Tipar selama kegiatan KKN sangat koperatif dan supporting untuk terlibat dalam penerapan programprogram kerja mahasiswa KKN, sehingga program kerja yang diterapkan dapat terealisasi secara maksimal.

3. Realisasi program-program $\mathrm{KKN}$ di Desa Batujajar secara langsung memberi dampak perubahan pada cara berpikir masyarakat, seperti pemahaman tentang konsep pendidikan, ekonomi kreatif dan kesehatan, sedangkan kondisi fisik berupa adanya fasiltas bak sampah dan fasilitas pendidikan di PAUD dan SD. 


\section{DAFTAR PUSTAKA}

Danim, Sudarwan. 2002. Menjadi Peneliti Kualitatif. Bandung: Pustaka Setia

Fatimah, Fety. 2018. Pengabdian Masyarakat Menuju Desa Pamegarsari Yang Mandiri Melalui Peningkatan Pendidikan. ABDIDOS. Volume 02 (Nomor 02, Juni 2018): 138-146.

Kasman, Rusdi. 2018. Memberdayakan Masyarakat Dalam Meningkatkan Kualitas Hidup Melalui Bidang Pendidikan, Lingkungan, Ekonomi Dan Kesehatan. ABDIDOS. Volume 02 (Nomor 02, Juni 2018): 196-204.

$\begin{array}{ccr}\text { Rosyadi, } & \text { Rahmat.2019. } & \text { Petunjuk } \\ \text { Pelaksanaan } & \text { KKN } & \text { Tematik } \\ \text { Terintegrasi } 2019 & \text { UIKA } & \text { Bogor. } \\ \text { Bogor: UIKA Press } & & \end{array}$

Prasetya, E. (2018). Pemberdayaan Masyarakat Tentang Kesehatan, Pendidikan dan Kreatifitas. Abdi Dosen: Jurnal Pengabdian Pada Masyarakat 2 (1), 19-25.

Prasetya, E. (2020). 10 Characteristics of SMK Teachers in the Industrial Era 4.0 (Case Study at SMK Bina Profesi Bogor). Edumaspul: Jurnal Pendidikan, 4(1), 50-55. https://doi.org/10.33487/edumaspul.v 4i1.297Salinan Undang-Undang Nomor 14 Tahun 2005 tentang Guru dan Dosen.

Salinan Undang-Undang Nomor 18 tahun 2008 tentang pengelolaan persampahan. 